\title{
EFEITOS DA SUPLEMENTAÇÃO DE LICOPENO ISOLADO E NA MATRIZ ALIMENTAR SOB MARCADORES DE LESÃO HEPÁTICA DE RATAS ALIMENTADAS COM DIETA HIPERLIPÍDICA
}

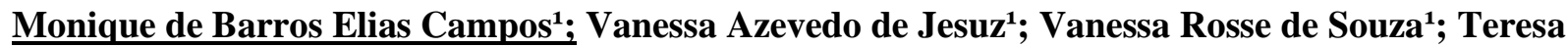 \\ Palmisciano Bedê²; Vilma Blondet de Azeredo²; Anderson Junger Teodoro' \\ (moniquebarros.nutri@gmail.com) \\ 1Programa de Pós Graduação em Alimentos e Nutrição (PPGAN) - Universidade Federal do Estado do Rio de \\ Janeiro (UNIRIO), Brasil; ${ }^{2}$ Universidade Federal Fluminense (UFF), Brasil.
}

Introdução: A alta atividade energética do fígado gera um consumo aumentado de oxigênio, o que acarreta em elevada produção de radicais livres envolvidos na fisiopatologia de doenças inflamatórias e danos potenciais a proteínas, lipídios e ao DNA celular. Estudos vêm demonstrando a ação do licopeno na histopatologia do carcinoma hepatocelular e na proteção do fígado devido sua ação antioxidante. Objetivo: Estudar os efeitos do licopeno sintético e de molho de tomate na avaliação de marcadores de lesão hepática de ratas alimentadas com dieta hiperlipídica. Material e Métodos: Foram utilizados 50 Rattus novergicus Wistar albino, fêmeas, adultas, distribuídas em seis grupos $(\mathrm{n}=5)$, da seguinte forma: Grupo Controle (GC); Grupo Hiperlipídico - (GH); Grupo Molho de Tomate - contendo $2 \mathrm{mg} / \mathrm{kg} / \mathrm{dia}$ de licopeno na solução, (GT); Grupo Licopeno - 2 mg/kg/dia (GL2); Grupo Licopeno - 4 mg/kg/dia (GL4); Grupo Licopeno $-8 \mathrm{mg} / \mathrm{kg} / \mathrm{dia}$ (GL8). Ração e água foram ofertados ad libitum e as soluções foram ofertadas diariamente através de suplementação oral durante 60 dias. Todos os dados de peso corporal, de consumos alimentar e das soluções suplementadas foram registrados em planilhas individuais durante os dias de cuidado, até o fim do experimento. Com o registro dos dados foi possível verificar a variação de peso dos animais ao longo do estudo, assim como estimar o consumo médio de ração e das bebidas de cada grupo de animais. Ao final do experimento, os animais foram mantidos em jejum e sacrificados $\mathrm{O}$ fígado dos animais foi extraído, pesado e as células hepáticas foram analisadas por citometria de fluxo, utilizando anexina/PI como marcadores de apoptose. Amostras de sangue foram coletadas para determinar as concentrações de aspartato transaminase (AST) e alanina transaminase (ALT) em aparelho automatizado. Para comparação de médias entre grupos foi utilizado Anova one-way e Tukey como pósteste, considerando p<0,05. Resultados: Os grupos GL2 $(196,8 \mathrm{~g} \pm 9,08)$ e GL4 $(188,8 \mathrm{~g} \pm 6,18)$ induziram uma diminuição significativa do peso dos animais em comparação ao GC (261g $\pm 10,06)$, porem os grupos MT e GL8 não demosntraram diminuição significativa no peso corporal quando comparados ao controle. Na avaliação de enzimas hepáticas (AST e ALT), observou-se que não houve diferença significativa entre os grupos tratados e não tratados. Todos os grupos apresentaram índice hepatossomático (g fígado/100g peso corporal) semelhante - GC (2,71 $\pm 0,18)$, GH $(2,76 \pm 0,13)$, GL2 $(2,82 \pm 0,18)$, GL4 $(2,75 \pm 0,21)$, GL8 $(2,79 \pm 0,22)$ e GMT $(2,74 \pm 0,19)$. Assim, não houve diferença significativa na avaliação do peso do fígado sobre o peso corporal dos animais. Na avaliação da apoptose, foi constatado um aumento de células em apoptose no GH $(22,98 \pm 7,78)$ quando comparado ao GC $(2,18 \pm 1,55)$. Após o tratamento com licopeno isolado (GL2 - 11,92 \pm 8,74, GL4 - 5,58 $\pm 1,43$ e GL8 -8,55 $\pm 3,06$ ) e com molho de tomate (GMT- 10,02 $\pm 3,1$ ), ocorreu uma diminuição acentuada no percentual de células em apoptose em relação ao $\mathrm{GH}$, não havendo diferença entre as doses de licopeno utilizadas e entre os grupos tratados com licopeno e molho de tomate. Conclusão: $O$ licopeno promoveu uma melhora na resposta celular através da redução de apoptose, sugerindo efeito hepatoprotetor contra modificações celulares causadas pela dieta hiperlipídica.

Palavra chave: licopeno; antioxidante; lesão hepática 